Fracturing and crystal plastic behaviour of garnet under seismic stress in the dry lower continental crust (Musgrave Ranges, Central Australia)

\author{
Journal Article \\ Author(s): \\ Hawemann, Friedrich; Mancktelow, Neil (D); Wex, Sebastian; Pennacchioni, Giorgio; Camacho, Alfredo \\ Publication date: \\ 2019 \\ Permanent link: \\ https://doi.org/10.3929/ethz-b-000371749
}

Rights / license:

Creative Commons Attribution 4.0 International

Originally published in:

Solid Earth 10(5), https://doi.org/10.5194/se-10-1635-2019

Funding acknowledgement:

146745 - Interplay between Fracture and Flow during Localization of Deformation in the Middle and Lower Crust (SNF) 


\title{
Fracturing and crystal plastic behaviour of garnet under seismic stress in the dry lower continental crust (Musgrave Ranges, Central Australia)
}

\author{
Friedrich Hawemann $^{1}$, Neil Mancktelow ${ }^{1}$, Sebastian Wex ${ }^{1}$, Giorgio Pennacchioni ${ }^{2}$, and Alfredo Camacho $^{3}$ \\ ${ }^{1}$ Department of Earth Sciences, ETH Zurich, 8092 Zurich, Switzerland \\ ${ }^{2}$ Department of Geosciences, University of Padova, Padua, Italy \\ ${ }^{3}$ Department of Geological Sciences, University of Manitoba, Winnipeg, Manitoba, R3T 2N2, Canada
}

Correspondence: Friedrich Hawemann (friedrich.hawemann@erdw.ethz.ch)

Received: 10 June 2019 - Discussion started: 14 June 2019

Revised: 1 September 2019 - Accepted: 6 September 2019 - Published: 9 October 2019

\begin{abstract}
Garnet is a high-strength mineral compared to other common minerals such as quartz and feldspar in the felsic crust. In felsic mylonites, garnet typically occurs as porphyroclasts that mostly evade crystal plastic deformation, except under relatively high-temperature conditions. The microstructure of granulite facies garnet in felsic lowercrustal rocks of the Musgrave Ranges (Central Australia) records both fracturing and crystal plastic deformation. Granulite facies metamorphism at $\sim 1200 \mathrm{Ma}$ generally dehydrated the rocks and produced millimetre-sized garnets in peraluminous gneisses. A later $\sim 550 \mathrm{Ma}$ overprint under sub-eclogitic conditions $\left(600-700^{\circ} \mathrm{C}, 1.1-1.3 \mathrm{GPa}\right)$ developed mylonitic shear zones and abundant pseudotachylyte, coeval with the neocrystallization of fine-grained, high-calcium garnet. In the mylonites, granulite facies garnet porphyroclasts are enriched in calcium along rims and fractures. However, these rims are locally narrower than otherwise comparable rims along original grain boundaries, indicating the contemporaneous diffusion and fracturing of garnet. The fractured garnets exhibit internal crystal plastic deformation, which coincides with areas of enhanced diffusion, usually along zones of crystal lattice distortion and dislocation walls associated with subgrain rotation recrystallization. The fracturing of garnet under dry lowercrustal conditions, in an otherwise viscously flowing matrix, requires transient high differential stress, most likely related to seismic rupture, consistent with the coeval development of abundant pseudotachylyte.
\end{abstract}

\section{Highlights.}

- Garnet is deformed by fracturing and crystal plasticity under dry lower-crustal conditions.

- Ca diffusion profiles indicate multiple generations of fracturing.

- Diffusion is promoted along zones of higher dislocation density.

- Fracturing indicates transient high-stress (seismic) events in the lower continental crust.

\section{Introduction}

A fundamental problem in geology is the limited preservation of processes in the rock record. This is especially the case for transient events, like earthquakes, as traces of these are hardly preserved due to later reworking. The best indicators for seismicity in the rock record are pseudotachylytes (Sibson, 1975; Toy et al., 2011), although not every seismic event produces frictional melts and, once formed, ductile creep or later brittle fracturing may erase most traces (Sibson and Toy, 2006; Kirkpatrick and Rowe, 2013).

Garnet is stable in many metamorphic rocks over a large part of the pressure-temperature space, is commonly preserved, and is suitable for a range of geothermobarometers and geochronometers and their combination for 
geospeedometry (Lasaga, 1983; Caddick et al., 2010; Baxter and Scherer, 2013). Being a high-strength mineral (Karato et al., 1995; Wang and Ji, 1999), both brittle and crystal plastic deformation are rarely observed in garnet when compared to the common matrix minerals of the crust, such as quartz and feldspar. However, Dalziel and Bailey (1968) already interpreted elongate garnets in high-grade mylonites to be the result of crystal plastic behaviour, and advancements since then in electron microscopy, and especially EBSD (electron backscatter diffraction), have allowed for a detailed investigation of garnet textures (Kunze et al., 1993; Prior et al., 2000, 2002).

Experimental deformation of garnet indicates that differential stresses on the order of a few gigapascals are required to produce shear fractures and that the onset of crystal plastic behaviour for strain rates typical of actively deforming regions $\left(10^{-12}-10^{-15} \mathrm{~s}^{-1}\right.$; e.g. Behr and Platt, 2011) should only occur at corresponding temperatures above ca. 640$750{ }^{\circ} \mathrm{C}$ (Karato et al., 1995; Wang and Ji, 1999). The observation of fractured garnets in natural samples may therefore be linked to seismic stresses, as suggested by Austrheim et al. (1996), who described the fracturing of garnets during pseudotachylyte formation and fluid-assisted eclogitization of granulites. Trepmann and Stöckhert (2002) also interpreted the microstructure of fractured and offset garnets as evidence for synseismic loading and post-seismic creep. More recently, both brittle (Austrheim et al., 2017; Engi et al., 2017; Angiboust et al., 2017; Giuntoli et al., 2018; Hawemann et al., 2018; Petley-Ragan et al., 2019) and associated crystal plastic behaviour (Austrheim et al., 2017; Petley-Ragan et al., 2019) of garnet have been related to seismic events in lower continental crust or deeply subducted continental fragments. Papa et al. (2018) interpreted similar deep-seated dilatant fracturing of garnet immediately adjacent to pseudotachylyte to be related to thermal shock due to frictional heating rather than to damage associated with the propagation of the seismic rupture. Konrad-Schmolke et al. (2007) described enhanced diffusion of $\mathrm{Mg}$ along subgrain boundaries in garnet (but not of slowdiffusing elements, such as $\mathrm{Ca}$, Ti and $\mathrm{Y}$ ) from high-pressure meta-granitoids of the deeply subducted Sesia Zone (Western Alps). However, in contrast to more recent studies in the Sesia Zone, which propose that precursor fracturing was crucial for dissolution-precipitation and diffusion processes in garnet (Engi et al., 2018; Giuntoli et al., 2018), they considered that there were no signs of crystal plastic deformation in their garnet samples and concluded that a diffusion-induced dislocation migration and/or diffusion-induced recrystallization process was responsible for the development of the observed subgrain texture.

Garnets can retain their microstructure and chemical composition during retrograde deformation and metamorphism and can therefore preserve indicators for seismic events, which are otherwise possibly erased from the rock record.
Here we present a study of garnet microstructures from lower crustal rocks of the Musgrave Block in Australia, which

1. illustrates the close association between brittle and crystal plastic deformation of garnet under well-established pressure-temperature conditions;

2. infers deformation mechanisms from the observed microstructure;

3. explores the close link between deformation and diffusion in garnet;

4. complements other independent observations indicating transient high stresses in the lower crust.

\section{Geological setting}

\subsection{Regional geology}

The Musgrave Block is located in an intraplate position close to the centre of the Australian continent (inset Fig. 1). Amalgamation of the different cratonic blocks took place during the Musgravian Orogeny (1120-1200 Ma), which pervasively overprinted ca. 1550 Ma gneisses (Gray, 1978; Camacho and Fanning, 1995). The Petermann Orogeny ( $550 \mathrm{Ma}$ ) produced a series of crustal-scale fault zones, most prominently the Woodroffe Thrust and the Mann Fault (Collerson et al., 1972; Major, 1973; Bell, 1978; Camacho and Fanning, 1995; Raimondo et al., 2010; Hawemann et al., 2018, 2019; Wex et al., 2017, 2018, 2019). The south-dipping Woodroffe Thrust has a top-to-the-north sense of shear, and it juxtaposes the Fregon Subdomain in the south (hanging wall) against the Mulga Park Subdomain in the north (footwall). During the Musgravian Orogeny, the Mulga Park Subdomain attained amphibolite facies conditions, while the Fregon Subdomain reached granulite facies (Camacho and Fanning, 1995; Scrimgeour et al., 1999; Scrimgeour and Close, 1999) and depleted the rocks of OH-bearing minerals (Wex et al., 2018; Hawemann et al., 2018).

The Woodroffe Thrust hosts one of the largest occurrences of pseudotachylyte worldwide (Camacho et al., 1995), but all larger-scale shear zones in the hanging wall also show abundant pseudotachylyte that developed under lower-crustal conditions (Camacho, 1997; Hawemann et al., 2018). Deformation in the Fregon Subdomain associated with the Petermann Orogeny is concentrated along the sub-eclogitic $(\sim$ $650^{\circ} \mathrm{C}, 1.2 \mathrm{GPa}$ ) Davenport Shear Zone and the North Davenport Shear Zone (Fig. 1), with little discernible overprint of the earlier granulites in between (Camacho et al., 1997). The Davenport Shear Zone is a WNW-ESE-striking strike-slip zone, with a near horizontal stretching lineation. Deformation inside the Davenport Shear Zone itself is heterogeneous and strongly localized (Hawemann et al., 2019). 


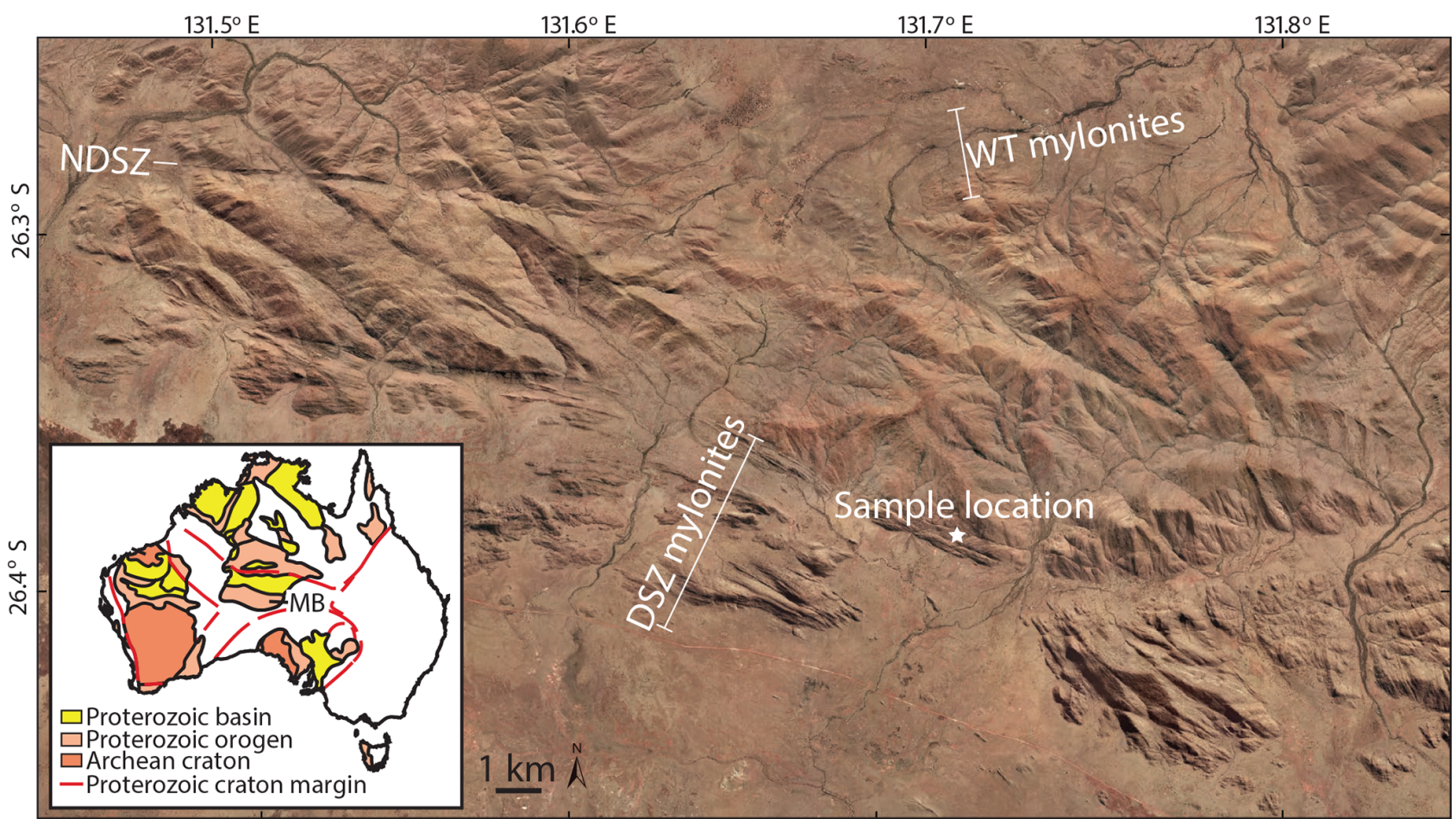

Figure 1. Airborne imagery of the study area with the sample location $\left(26.3849^{\circ} \mathrm{S}, 131.7067^{\circ} \mathrm{E}\right)$ in the Davenport Shear Zone (DSZ). NDSZ stands for the North Davenport Shear Zone, and WT stands for the Woodroffe Thrust. The image is from the Department of Primary Industries and Regions, South Australia (PIRSA), 2012. The inset is the location of the Musgrave Block (MB) in between the amalgamated Australian cratons. This was modified after Evins et al. (2010).

\subsection{Sample description}

Fractured garnet is ubiquitous in the Fregon Subdomain and is not exclusively found in association with pseudotachylyte veins. However, this study focuses on a representative outcrop for which field relationships, metamorphic and deformation conditions have been well established (F68, Hawemann et al., 2018; $26.3849^{\circ} \mathrm{S}, 131.7067^{\circ} \mathrm{E}$ ). This outcrop consists of a quartzo-feldspathic mylonite with millimetresized granulite facies garnets and includes multiple pseudotachylyte veins and breccias. Pseudotachylytes in the studied outcrop are sheared, as indicated by elongated clasts (Fig. 2a, c), and show the same stretching lineation as the host mylonite. The original discordant relationship to the host foliation is still preserved, with the crosscutting relationship most obvious in sections perpendicular to the stretching lineation (Fig. 2b).

The synmylonitic assemblage associated with the Petermann overprint of the felsic granulites is $\mathrm{Qz}+\mathrm{Kfs}+\mathrm{Pl}+\mathrm{Gt}+\mathrm{Bt}+\mathrm{Ky}+\mathrm{Ilm}+\mathrm{Rt}$ (mineral abbreviations following Whitney and Evans, 2010) and is similar to that of the associated sheared pseudotachylyte $(\mathrm{Qz}+\mathrm{Kfs}+\mathrm{Pl}+\mathrm{Gt}+\mathrm{Bt}+\mathrm{Ky}+\mathrm{Rt}) \quad$ (Hawemann et al., 2018). The fine-grained garnet growing within the pseudotachylyte gives the rock its macroscopic caramel colour (Fig. 2). Larger fractured garnets within the granulites are clearly recognizable in polished hand specimens (Fig. 2c) and are very apparent in a thin section (Fig. 3). The metamorphic conditions during shearing of this pseudotachylyte are estimated at $\sim 600^{\circ} \mathrm{C}$ and $\sim 1.1 \mathrm{GPa}$ (Fig. 7 of Hawemann et al., 2018).

\section{Garnet microstructure and compositional variation}

\subsection{Optical microstructure}

Granulite facies garnet porphyroclasts in Musgravian peraluminous gneisses that were mylonitized during the Petermann Orogeny are almost invariably fractured, irrespective of their proximity to pseudotachylyte (Fig. 3). Large garnet porphyroclasts $(>1 \mathrm{~mm})$ are typically slightly elongated with their long axis parallel to the foliation, which is attributed at least partially to resorption. Fractures in garnets often show offsets on the order of a few hundred micrometres. It is not possible to determine whether these offsets are primarily due to the initial shear fracture or result from subsequent sliding during ongoing ductile shearing. Moreover, no consistent sense of shear can be derived from the offsets (Fig. 3a, b). These discrete fractures are sub-planar, commonly have a consistent orientation at a moderate angle to the foliation and locally occur in conjugate sets (Fig. 3b). Wide fractures are 


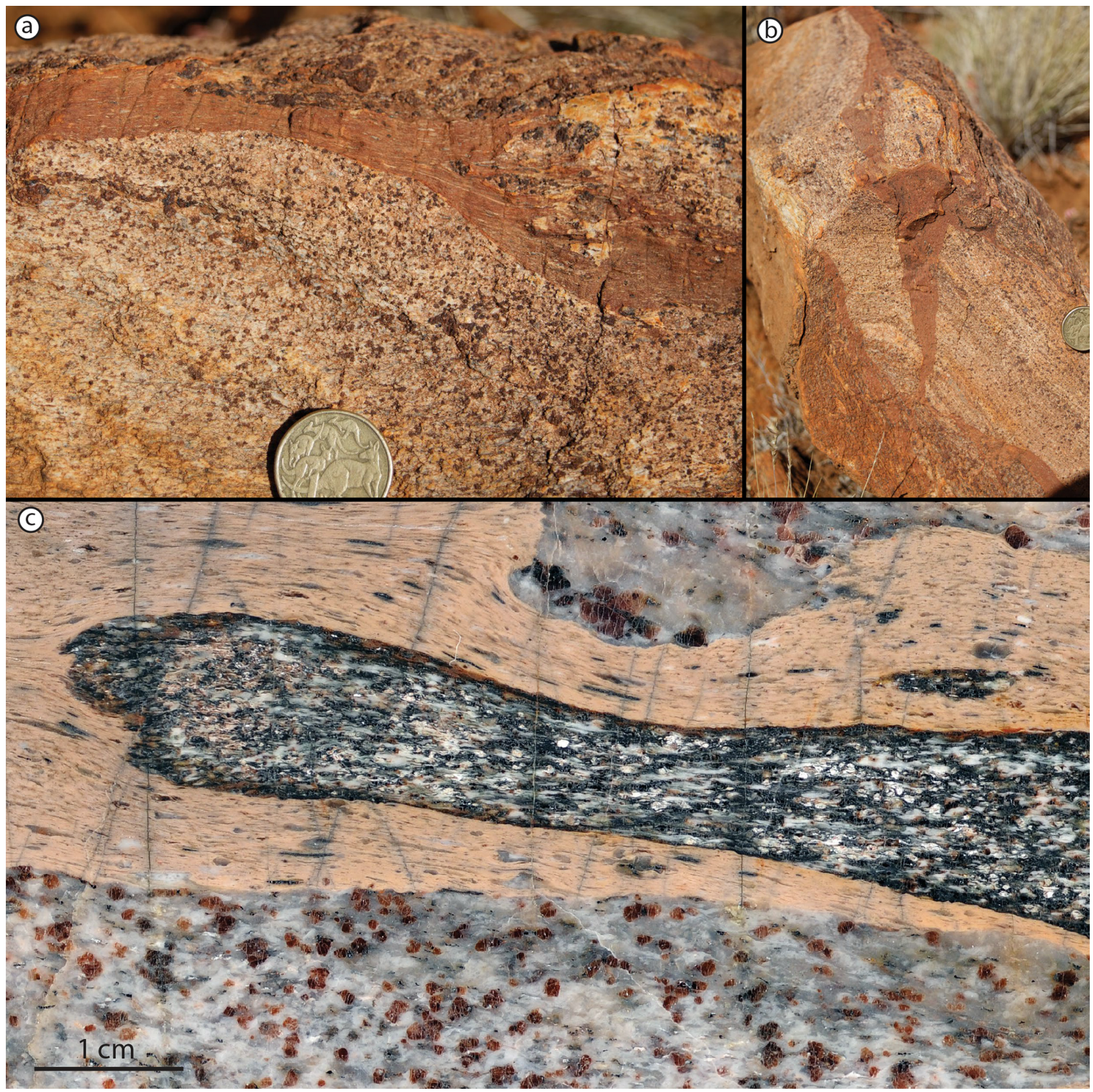

Figure 2. Sheared pseudotachylyte in a view orthogonal to the foliation of host felsic mylonite and looking (a) perpendicular and (b) parallel to the stretching lineation. (c) Polished hand specimen of a sheared pseudotachylyte breccia with the caramel-coloured foliated pseudotachylyte matrix including elongated clasts and an elongated fragment of mafic granulite. The host rock shows millimetre-sized garnets with fractures. The plane of the polished surface is perpendicular to the foliation and parallel to the stretching lineation.

filled with biotite, kyanite and quartz (Fig. 4b). A later generation of unfilled fractures, without any discernible offset, is oriented perpendicular to both the foliation and stretching lineation (Fig. 3b). Garnet porphyroclasts commonly contain rutile exsolution lamellae and inclusions of monazite and kyanite (Fig. A1 in Appendix). The latter are present as aggregates with an overall prismatic shape, possibly represent- ing pseudomorphs after sillimanite (Camacho and Fitzgerald, 2010).

\subsection{Analytical techniques}

Quantitative mineral compositions were measured with a JEOL JXA-8200 electron probe micro-analyser (EPMA), equipped with a tungsten filament, at the Institute of Geo- 


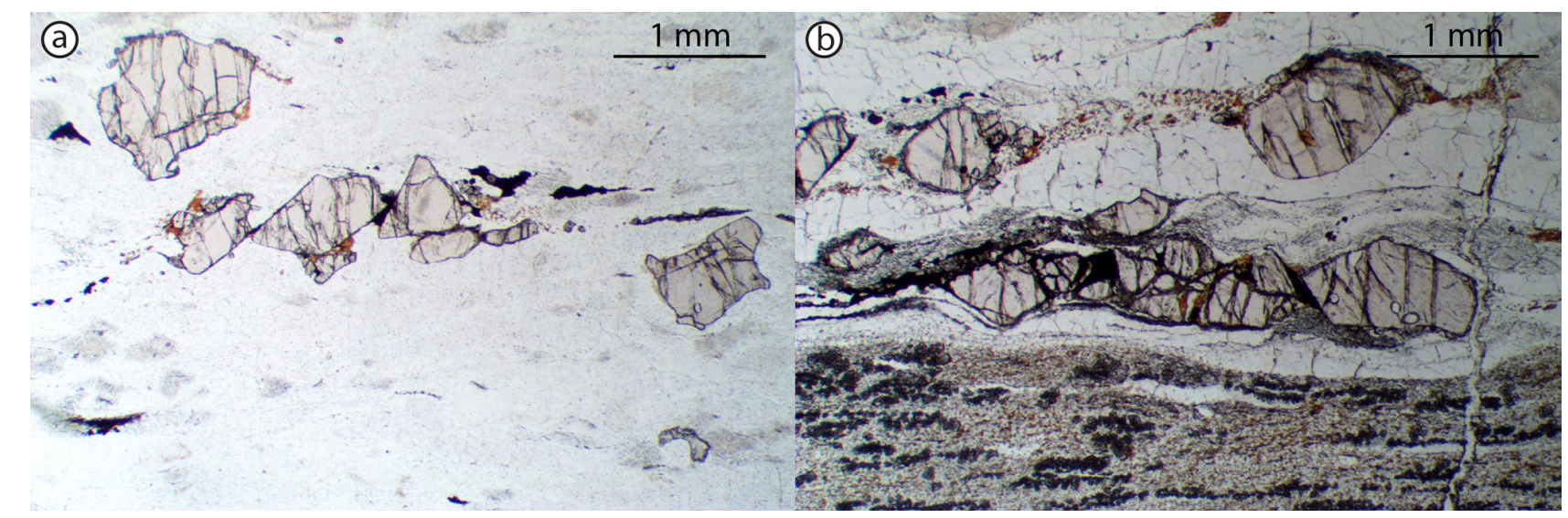

Figure 3. Thin-section photomicrographs in plane-polarized light of fractured garnets (a) away from pseudotachylyte and (b) close to sheared and recrystallized pseudotachylyte in the lower part of the image. The dark trails of grains elongated in the foliation of the sheared pseudotachylyte are small new garnets. The section is perpendicular to the foliation and parallel to the stretching lineation.

chemistry and Petrology at ETH Zurich (Switzerland). Natural standards were used for quantification, and, when available, natural garnet standards were preferred. To reach a spatial resolution of about $1 \mu \mathrm{m}$, an acceleration voltage of $10 \mathrm{kV}$ was set (Fig. 8 in Hofer and Brey, 2007). Elemental maps were acquired using energy wavelength-dispersive spectrometers in parallel for calcium, to increase the signal-to-noise ratio. Backscatter electron (BSE) images, energy-dispersive spectrometry (EDS) and electron backscatter diffraction (EBSD) mapping was carried out on a Quanta 200F field emission gun scanning electron microscope (FEG-SEM) at the ScopeM (Scientific Center for Optical and Electron Microscopy, ETH Zurich). EBSD maps were collected with an acceleration voltage of $20 \mathrm{kV}$, a sample tilt of $70^{\circ}$ and a working distance of $15 \mathrm{~mm}$. Data were post-processed using chemical indexing with the OIM Analysis 7 software by EDAX. When necessary, three different clean-up techniques were used: the neighbour confidence index correlation, neighbour orientation correlation and grain dilation. Point and map analyses, as well as BSE images, were combined for correlation with optical microscope images in a project using the QGIS software programme from the Open Source Geospatial Foundation. Two lamellae were cut with a focused ion beam (FIB) for transmission electron microscopy (TEM). The microscope used for TEM is a Tecnai F30 with an FEG source operated at $300 \mathrm{kV}$ and equipped with a Gatan 794 MultiScan charge-coupled device (CCD) (ScopeM, ETH Zurich).

\subsection{Compositional gradients}

Granulite facies garnet has a homogeneous composition of $X_{\text {Alm }} 0.54, X_{\text {Pyp }} 0.40, X_{\text {Grs }} 0.03$ and $X_{\text {Sps }} 0.03$, whereas garnet neocrystallized during the Petermann Orogeny is more Ca-rich $\left(X_{\text {Alm }} 0.48, X_{\text {Pyp }} 0.28, X_{\text {Grs }} 0.22\right.$ and $\left.X_{\text {Sps }} 0.02\right)$. Grain boundaries of granulite facies garnet and fractures are decorated with a Ca-enriched rim, 20 to $40 \mu \mathrm{m}$ wide (Fig. 4c). The length scale for variation in $\mathrm{Fe}\left(X_{\mathrm{Alm}}\right)$ and $\mathrm{Mg}\left(X_{\mathrm{Pyp}}\right)$ is identical to that for $\mathrm{Ca}\left(X_{\mathrm{Grs}}\right)$, whereas the Mn content $\left(X_{\mathrm{Sps}}\right)$ does not show any variation (Fig. 4d). Neocrystallized garnet is present where the grain boundary is in contact with or close to plagioclase. The outermost rim of remnant garnet has the same composition as the neocrystallized garnet (Fig. 4d, profile 1). The granulite facies plagioclase is partially transformed to a more Na-rich plagioclase with needle-shaped inclusions of kyanite (bottom of Fig. 4e). This reaction provides $\mathrm{Ca}$ for the observed diffusion into garnet (Camacho et al., 2009).

Along fractures across the porphyroclasts, the Ca enrichment is narrower than along the grain boundaries, and the grossular component only reaches up to about $X_{\mathrm{Grs}} 0.1$ (Fig. 4d, profile 2). Compositional gradients are also present around inclusions in garnet connected to the outer garnet boundary, providing evidence of $\mathrm{Ca}$ diffusion along grain boundaries (right part of Fig. 4c, profile 3 in Fig. 4d). Profile 4 (Fig. 4d) was measured next to a kyanite inclusion: the diffusion length is still comparable to those of profiles 1-3, but $\mathrm{Ca}$ concentrations are much lower. Ca probably diffused along fractures (invisible in the plane of the thin section) towards the inclusion. In summary, the diffusion length at the original grain boundaries is maximized where it is in contact with plagioclase, and otherwise its width is constant at about $20 \mu \mathrm{m}$. However, variations in diffusion lengths do occur around garnet fragments, without any correlation with the proximity to plagioclase, although the exact relationship in the third dimension is unknown. Surfaces with limited diffusion can often be identified as fracture surfaces, which were exposed to diffusion for a shorter time than original grain boundaries (Fig. 4e). Fractures oriented perpendicular to the foliation and stretching lineation lack any signs of diffusion and are therefore interpreted as later-stage extensional fractures. 


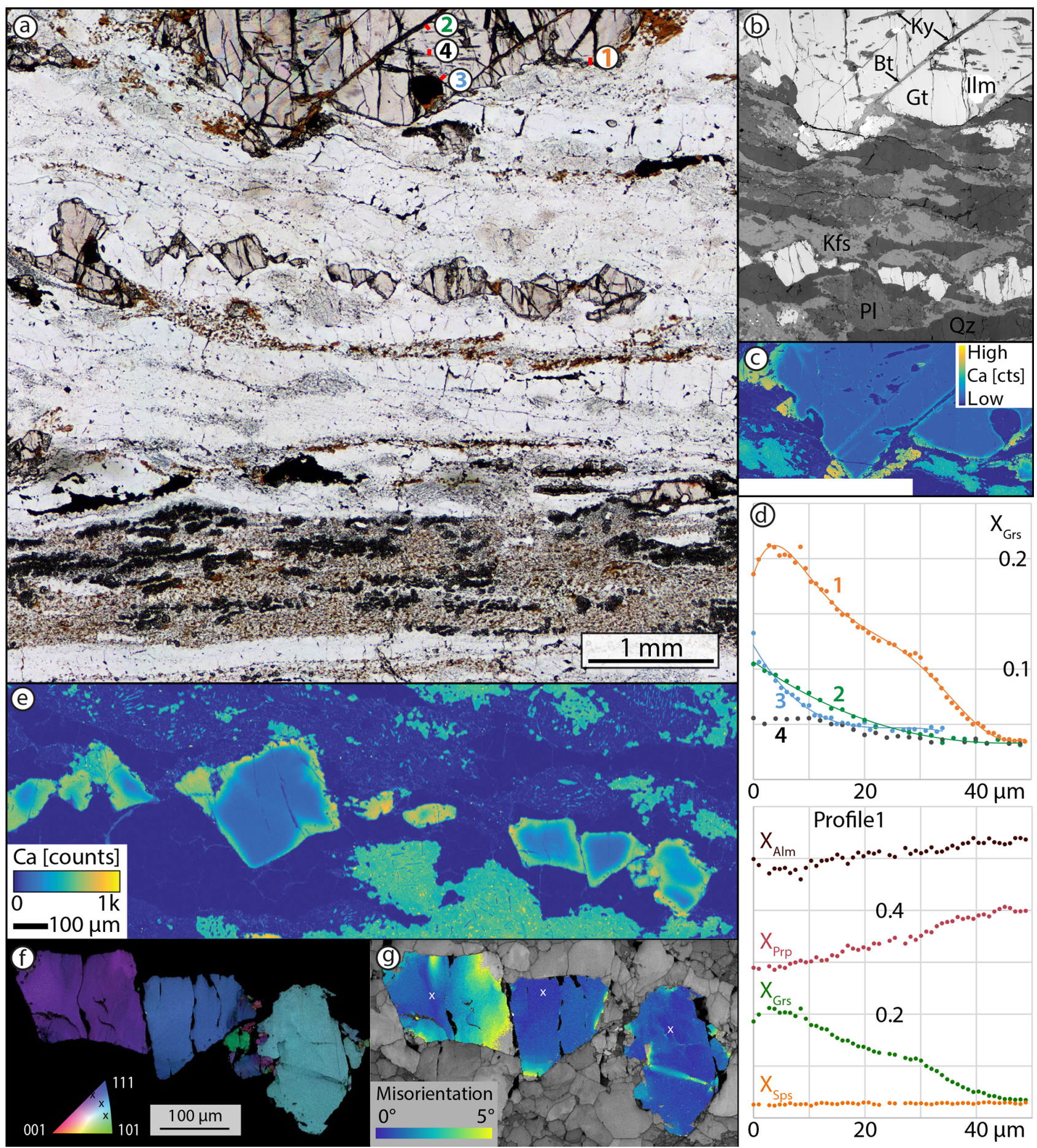

Figure 4. (a) A plane-polarized light image of the thin section with fractured garnets and a pseudotachylyte vein in the lower part of the image. (b) A BSE image of the upper area of (a), with the same scale as (a). (c) An EPMA X-ray map for Ca reveals an enrichment in thin gradational rims along grain boundaries and fractures and within neocrystallized garnet (euhedral, orange). (d) Grossular component profiles indicated on (a) (profile lines are not to scale for the sake of visibility) and compositional profiles for four garnet end-members in profile 1. (e) An EPMA X-ray map for Ca for the garnet fragments in the centre of (a). Note the uneven colours in the plagioclase and the blue kyanite needles. (f) An inverse pole figure map with a superimposed image quality map for garnet fragments shows a common rotation pole. (g) Misorientation map relative to the reference point for each fragment reveals internal lattice distortions. 
Some garnets display more complicated compositional patterns, with zones $>100 \mu \mathrm{m}$ of $\mathrm{Ca}$ enrichment extending into the porphyroclast's interior, which are not associated with fractures (e.g. the garnet fragment on the far right in Fig. 4e). EBSD analysis highlights that the three fragments in the right part of Fig. 4e most likely originated from the same grain, as they share a common rotation axis (Fig. 4f). The colours in the inverse pole figure map are not solid, reflecting slight variations of orientation within the crystal. Furthermore, the image quality map shows areas of suppressed Kikuchi patterns (grey value), which is suggestive of higher dislocation density and therefore possible subgrain boundaries (Fig. 4f). The misorientation angle map (Fig. 4g) reveals a complex pattern of varying crystal orientation (all within the order of $5^{\circ}$ ) in the fragments, with very distributed zones connected to the edges of the crystal, triangular-shaped zones of misorientation (upper left of Fig. $4 \mathrm{~g}$ ) and discrete zones (lower right of Fig. 4g). The discrete zones of misorientation, about $5 \mu \mathrm{m}$ wide, correlate well with the Caenriched zones (compare Fig. 4e, f, garnet fragment on the right).

\subsection{Texture of deformed garnets}

Two to three orientations of fractures are generally present in a single garnet crystal and coincide with the trace of the (101) plane derived from EBSD data (Fig. 5a, b). Fracture set (I) in the example of Fig. 5a is often associated with a relative rotation of both sides, as visible from the difference in colour. In the lower part of the grain, where the fracture density is very high, more subgrains are present. The subgrain spatial density increases towards the original grain boundary, and some subgrains are "eroded" by ductile shearing and strung out along the foliation. This demonstrates that ductile shearing outlasted subgrain formation and fracturing. The fractures described above are all crosscut by extensional fractures (set II in Fig. 5a), which are oriented perpendicular to the stretching lineation and foliation. These do not show any associated distortion of the crystal lattice.

The garnet porphyroclast of Fig. 5c shows a central fracture as well as a set of two other parallel fractures. The central fracture is the only one with a significant offset and is filled with kyanite and quartz. This fracture displays misorientations of more than $5^{\circ}$ towards the right-hand side of the scan, but it has none towards the left-hand side. In the lower left corner of the fragment, subgrains are observed with misorientations, relative to the average orientation, typically in the range of $10^{\circ}$. Misorientation axes are often parallel to (111) and (101). The lowermost fragment shows a wide zone of progressive rotation. The chemical profile in Fig. 5e shows the highest $\mathrm{Ca}$ counts towards the boundaries of the porphyroclasts and, internally, towards two fractures. The larger fracture with an apparent offset of the two garnet fragments exhibits a less well-developed zone of $\mathrm{Ca}$ enrichment when compared to the tight fracture with introduced lattice distortion.

\subsection{TEM investigations}

The garnet fragment of Fig. 4g was further investigated using TEM, as it includes a narrow zone of misorientation without fractures, and it is therefore suitable for the preparation of FIB lamellae. As visible in Fig. 6a (around profile 1), the image quality map shows a well-defined narrow, darker-grey band, possibly indicating high dislocation density. The zone is even more evident in the misorientation plot (Fig. 6b) and changes from about $5 \mu \mathrm{m}$ wide, with discrete boundaries to the right, to a wider $(>10 \mu \mathrm{m})$ band towards the left of the image. In the upper left part of the image, a subgrain boundary with $>5^{\circ}$ misorientation transitions into a zone of gradual misorientation. The misorientation axis is consistently parallel to (101) with minor rotation around (111) (Fig. 6c, Fig. A2). Misorientation profiles reveal a slight asymmetry within the narrow band, where the lower boundary appears to be sharper. Misorientation changes more gradually within the wider portion of the misorientation band. Locally, subgrains developed with discrete boundaries, documenting a misorientation of usually around $5-10^{\circ}$ (profile 3 in Fig. 6d). The FIB lamella was cut across the narrow band of misorientations (Fig. 6e). The lower boundary corresponds to a narrow discrete zone, without visible dislocations (Fig. 6f). The upper boundary is marked by a series of dislocation walls, and only a few free dislocations are visible, which are often organized in arrays (Fig. 6g, h). The existence of dislocation walls and subgrain boundaries indicates recovery by dislocation climb (e.g. Hobbs, 1968; Passchier and Trouw, 2005).

\section{Discussion}

Garnets in this study show evidence for both brittle and ductile deformation under relatively low temperatures of about $600^{\circ} \mathrm{C}$, as inferred from synchronous diffusion and ductile shearing of pseudotachylyte (Hawemann et al., 2018). This is below the experimentally determined values for the onset of crystal plastic deformation of garnet (Wang and Ji, 1999) at the higher strain rates considered typical of mylonitic shear zones $\left(>10^{-14} \mathrm{~s}^{-1}\right)$. In contrast to experiments, many natural examples (Vollbrecht et al., 2006; Bestmann et al., 2008; Austrheim et al., 2017) indicate that crystal plasticity of garnet can occur at lower temperatures between 650 and $700^{\circ} \mathrm{C}$.

The presence of microstructures and textures consistent with dislocation climb and recovery, as well as subgrain rotation, in garnet at around $600^{\circ} \mathrm{C}$ is in agreement with previous studies (Bestmann et al., 2008; Massey et al., 2011). No evidence for grain boundary sliding is observed, since subgrains show rotation around a specific crystallographic axis. Rotation around (111) and (101) is in accordance with the slip systems described by Voegelé et al. (1998). 


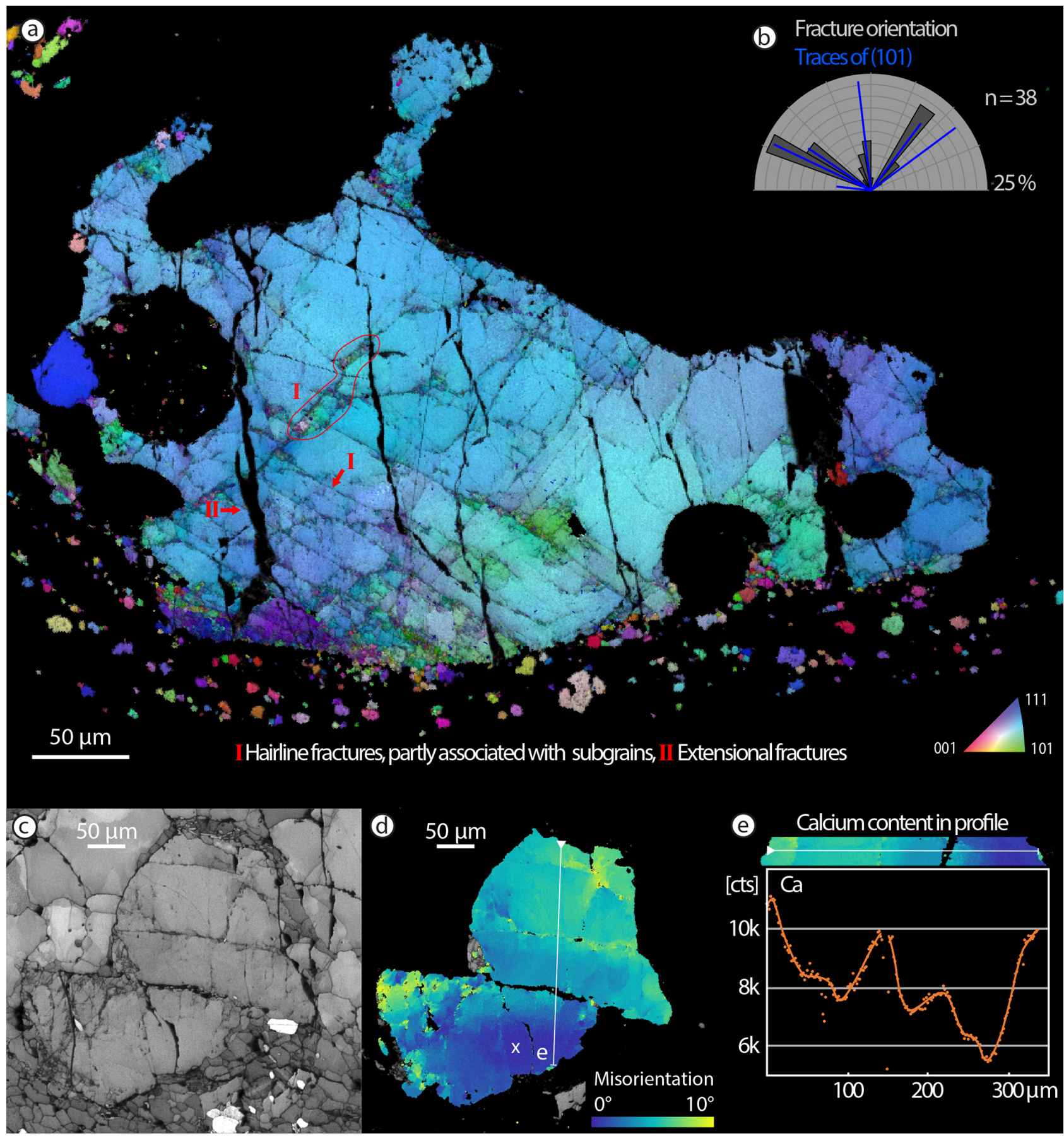

Figure 5. (a) An inverse pole figure map of fractured garnet with three dominant orientations of fractures. (b) A rose diagram correlating traced fracture orientations and (101) planes for garnet in (a). (c) An image quality map of a fragmented garnet with subgrains. (d) A misorientation plot (with respect to the point marked with the white $x$ ) shows long wavelength bending in the lower fragment and distortion in the crystal lattice induced by a fracture in the upper fragment. (e) EDS calcium counts for the profile marked as a thin white line in (d).

Multiple generations of overprinting fractures with different orientations demonstrate repeated fracturing events. Extensional fractures do not show any induced lattice distortion or diffusion and therefore occurred after the temperature had decreased to values too low for diffusion (Camacho et al.,
2009), possibly during exhumation (compare Prior, 1993 and Ji et al., 1997).

In contrast to the observations of Austrheim et al. (2017), Papa et al. (2018) and Petley-Ragan et al. (2019), from other examples in the deep continental crust, no "explosive fractur- 

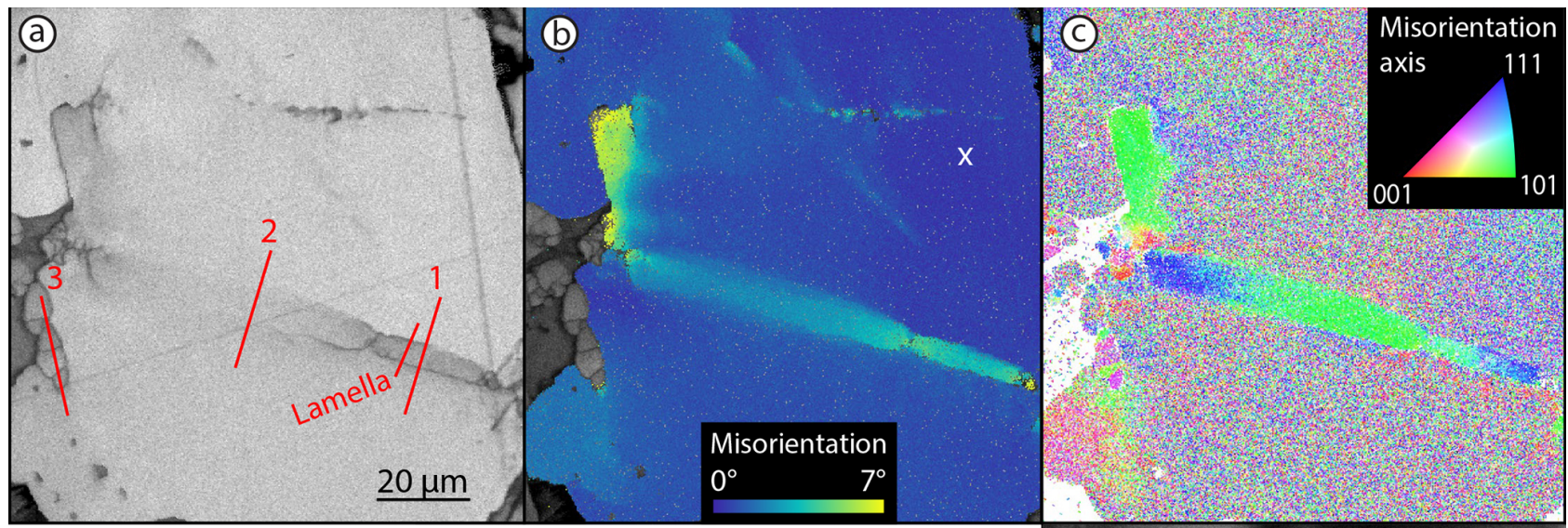

(d) Misorientation profiles
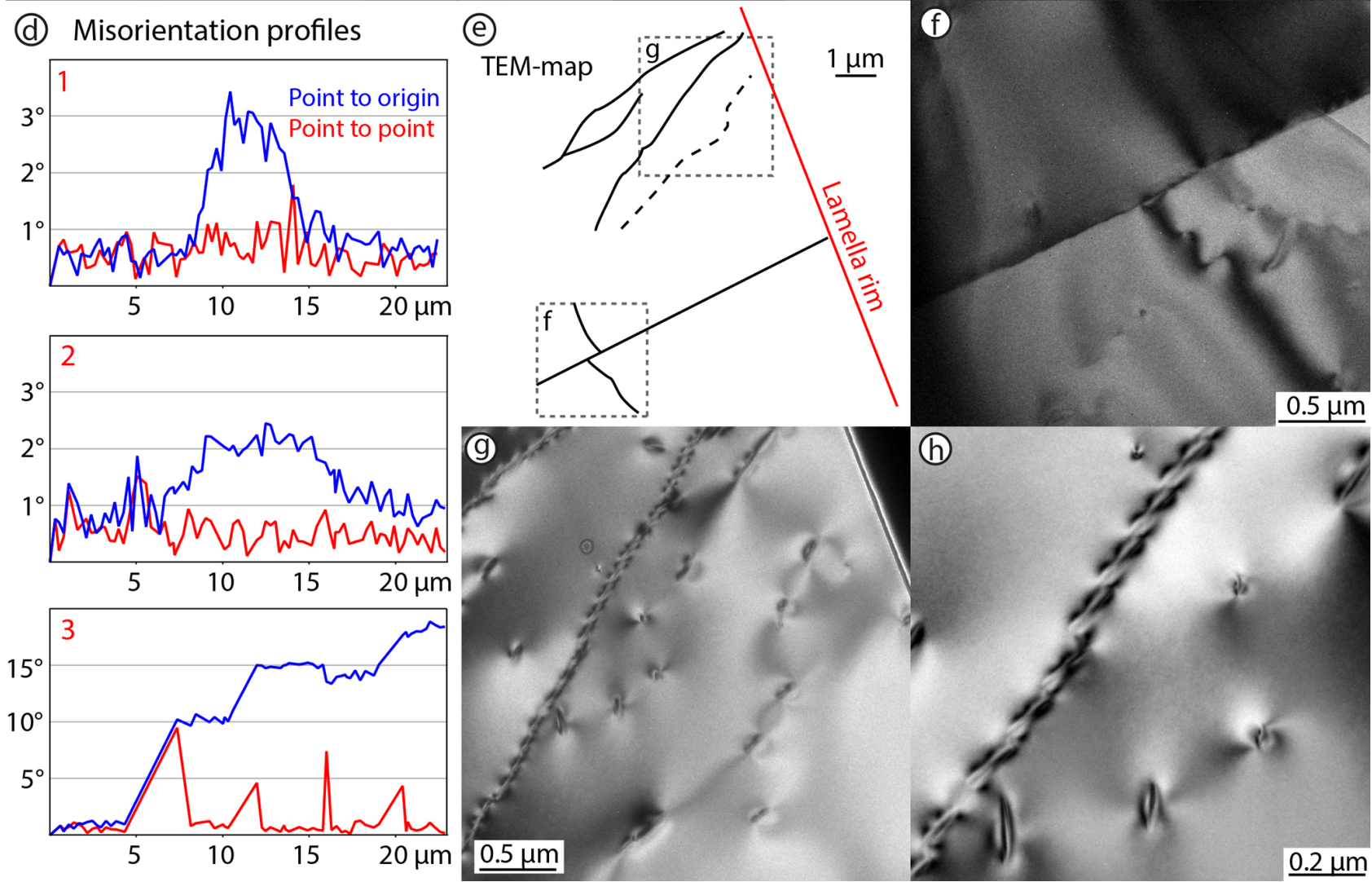

Figure 6. (a) An image quality map of the garnet fragment (compare Fig. 4f) with darker zones that can be interpreted as areas of high dislocation density and the location of the FIB lamella. (b) A misorientation plot with respect to the reference point (marked with the white $x$ ) shows a discrete zone of misorientation, which has discrete boundaries in the right part of the image but is more distributed towards the left. (c) A misorientation axis plot with respect to the average orientation of the grain shows a consistent rotation around the (101) and (111) axes. For pole figure plots, see Fig. A2. (d) Misorientation profiles indicated in (a) for (1) the narrow zone, (2) the more distributed zone and (3) subgrains. (e) An overview sketch of the FIB lamella used for TEM analysis for correlation with the EBSD data. (f) A sharp contrast boundary in the lower part of the lamella. (g) Two dislocation walls with a few free dislocations, which are partly linking up parallel to the dislocation walls. (h) Detail of the centre of (g).

ing", "shattering" or "fragmentation" of garnet is observed in relict porphyroclasts immediately adjacent to pseudotachylyte. The fractures described here are generally planar and often consistently oriented, in some cases showing single and conjugate shear offsets. Fractured garnet is not restricted to the boundary with pseudotachylyte and is still present even in samples without pseudotachylyte, where the nearest pseudotachylyte is possibly many metres or more away. Fracturing in this case cannot be related to thermal shock (Papa et al., 2018) or localized high stress due to (seismic) frac- 
ture propagation (Austrheim et al., 2017; Petley-Ragan et al., 2019), but it must reflect a larger-scale distribution of differential stresses in the lower crust that were, at least transiently, high enough to cause brittle-garnet failure (Hawemann et al., 2019). This could be due to stress pulses from earthquakes in the shallower brittle regime (Trepmann and Stöckhert, 2002; Ellis and Stöckhert, 2004; Jamtveit et al., 2018a, b, 2019) or a more local, lower-crustal source due to jostling of lessdeformed strong blocks within an irregular shear zone network (Hawemann et al., 2019).

The narrower $\mathrm{Ca}$ diffusion profiles on some fractures relative to garnet rims and crosscutting relationships suggest that fracturing was recurrent under sub-eclogite facies metamorphic conditions, as also indicated by the occasional presence of kyanite in some fractures. The presence of kyanite needles and the absence of zoisite/clinozoisite or epidote, as a breakdown product of plagioclase during sub-eclogitic metamorphism (Fig. 3b), indicate relatively dry lower-crustal conditions (Hawemann et al., 2018). According to Wayte et al. (1989), this indicates a water activity of $<0.004$, calculated for rocks of comparable composition and pressuretemperature conditions. However, new biotite did form in fractures across relict garnet, so conditions were probably not strictly anhydrous. The sheared and recrystallized pseudotachylyte developed a similar synkinematic assemblage as the host mylonite, demonstrating that there is also no marked partitioning of water into the frictional melt, which implies little free or bound water available in the original source rock (e.g. Wex et al., 2018). The effect of pore fluid pressure on the effective confining pressure must therefore have been negligible.

As reported in Hawemann et al. (2019), the dynamically recrystallized quartz grain size and microstructure in the host rock mylonites indicates that long-term flow stresses were not particularly high, on the order of less than $10 \mathrm{MPa}$. The ambient pressure of ca. 1.1-1.2 GPa determined for the host rocks should therefore be close to the lithostatic value (Mancktelow, 2008c). Figure 7 shows a simple linear plot of the Mohr-Coulomb failure criterion for an angle of internal friction of $30^{\circ}$ (coefficient $\mu=0.6$ ), a lithostatic load of $1.2 \mathrm{GPa}$ and no pore fluid pressure. This plot is only qualitative, since the angle of internal friction could decrease towards higher pressure (Shimada et al., 1983 ). However, the summary of experimental results in Byerlee (1978) indicates that there may be little change at least up to pressures similar to those considered here. It follows that the differential stress for fracture initiation must have been on the same order as the confining pressure (Fig. 7). As discussed in detail in Hawemann et al. (2019), such high differential stresses, leading to garnet fracture and the development of abundant pseudotachylyte, can only have been transient and presumably related to repeated short-term seismic events in the lower continental crust (Hawemann et al., 2018; Jamtveit et al, 2018a, b; Menegon et al., 2017). The lack of shattered garnet adjacent to pseudotachylyte in these samples may reflect drier condi-

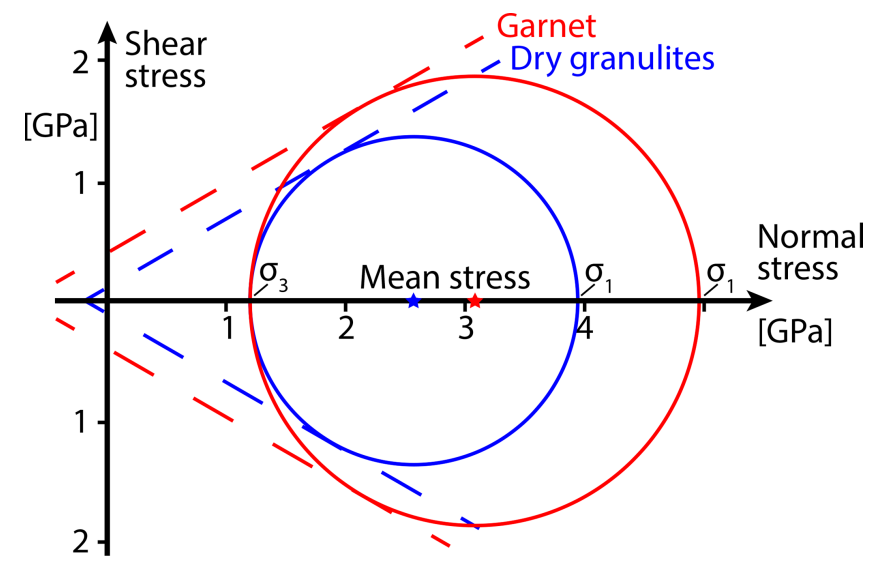

Figure 7. Mohr circles for the fracturing of dry granulites and garnet at a $1.2 \mathrm{GPa}$ lithostatic load.

tions relative to those in the Bergen Arc (Austrheim et al., 2017) and Mont Mary (Papa et al., 2018). The samples studied could therefore represent one end-member of the lower continental crust, where deformation occurs without the initial presence or influx of free water during fracturing and subsequent crystal plastic deformation.

\section{Conclusions}

In dry lower continental crust deformed under conditions of ca. $600^{\circ} \mathrm{C}$ and $1.1 \mathrm{GPa}$, garnet shows both single and conjugate sets of shear fractures, fractures with associated subgrains and induced lattice damage around fractures, subgrain formation without fracturing, and late-stage extensional fractures. Most of these fractures show a strong crystallographic control, with fracturing preferentially occurring along the (101) planes of garnet. Dynamic recrystallization is evident from inferred subgrain rotation recrystallization, and recovery is manifested by the presence of dislocation walls. The observed microstructures of garnets are interpreted to record transient high stresses during deep seismic events in the lower-crustal Fregon Subdomain. This is also indicated by the abundance of pseudotachylyte which developed under similar lower-crustal conditions and, possibly, by the variability of recrystallized quartz grain sizes including values down to a few micrometres (Hawemann et al., 2009). The studied example represents one end-member of lowercontinental-crustal behaviour where, due to earlier metamorphic dehydration and the intracratonic position well removed from the plate margin, rocks were initially dry and water was not introduced during fracturing and crystal plastic deformation.

Data availability. All data used in this paper can be accessed through the depository of the Open Science Framework at https://doi.org/10.17605/OSF.IO/YRZGH (Hawemann, 2019). 


\section{Appendix A}



Figure A1. (a) A thin-section image in plane-polarized light of a garnet crystal with monazite inclusions (with halos) and rutileexsolution needles. (b) A BSE image of the area indicated with the red box. 

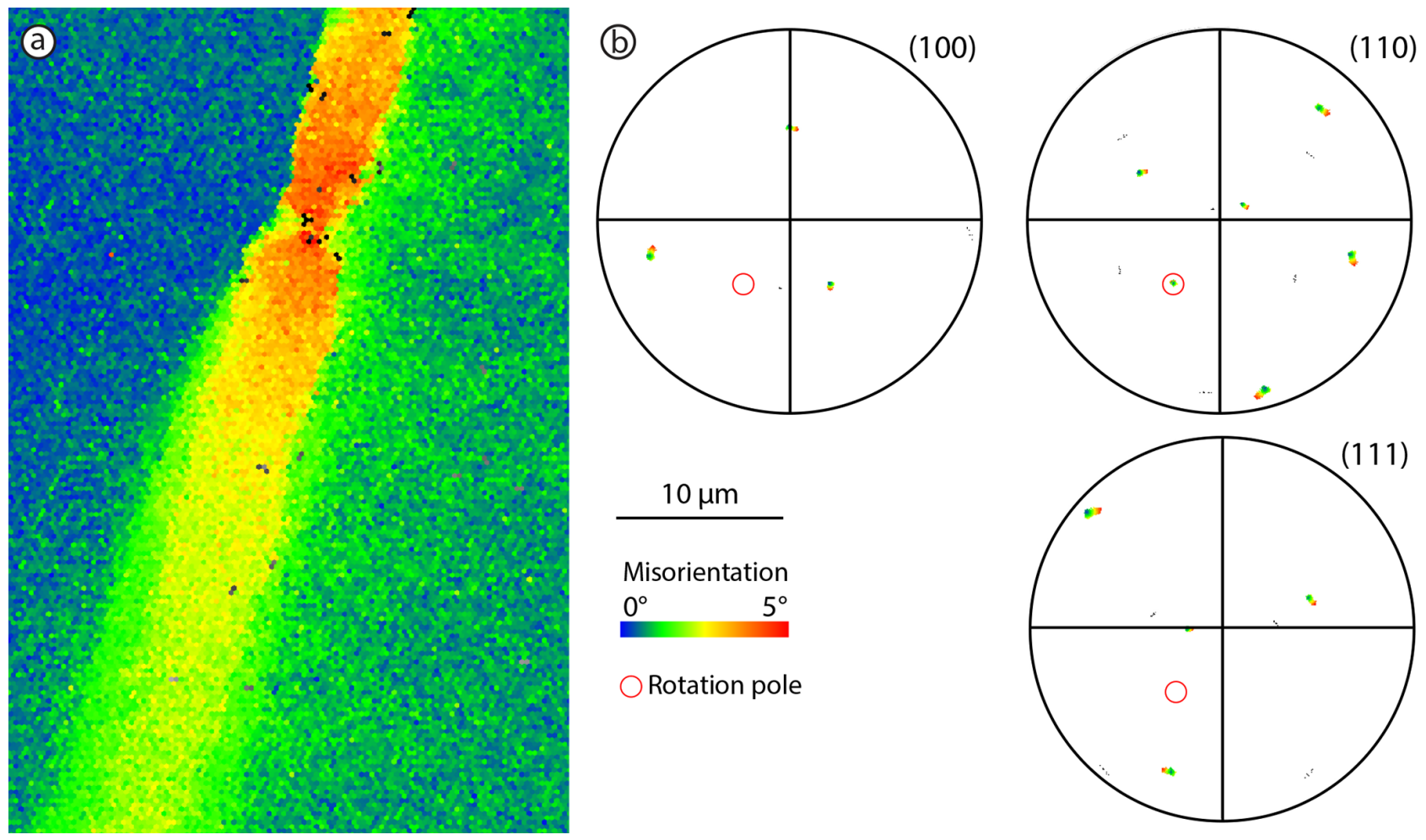

Figure A2. (a) A misorientation map detail for Fig. 6b, with (b) pole figure plots for the garnet axis with the same colour scheme. The plots reveal a rotation around a (101) axis, as indicated by the red circle. 
Author contributions. All authors listed took part in at least two of the three field seasons. NM assisted FH in data collection and interpretation. AC's and GP's knowledge in the field of garnet deformation and diffusion processes were crucial in preparing the paper. SW contributed to the microprobe work and research involving scanning electron microscopy. FH prepared the paper with contributions from all co-authors.

Competing interests. The authors declare that they have no conflict of interest.

Acknowledgements. We want to thank Matthias Konrad-Schmolke and an anonymous reviewer for their critical comments which improved the paper. We gratefully acknowledge permission granted to work on the Anangu Pitjantjatjara Yankunytjatjara (APY) lands to carry out our field work in the area. The Northern Territory Geological Survey (NTGS) and Basil Tikoff (Department of Geoscience, University of Wisconsin) are thanked for their logistical support and the Nicolle family of Mulga Park station for their hospitality. The Scientific Center for Optical and Electron Microscopy (ScopeM) provided the facilities for the scanning electron microscopy work, and help by Karsten Kunze, Luiz Morales and Fabian Gramm is especially acknowledged. Luca Menegon is thanked for his review of the first author's doctoral thesis.

Financial support. This research has been supported by the Swiss National Science Foundation (SNF; grant no. 200021_146745) and the University of Padova (grant no. BIRD175145/17).

Review statement. This paper was edited by Florian Fusseis and reviewed by Matthias Konrad-Schmolke and one anonymous referee.

\section{References}

Angiboust, S., Yamato, P., Hertgen, S., Hyppolito, T., Bebout, G. E., Morales, L.: Fluid pathways and high-P metasomatism in a subducted continental slice (Mt. Emilius klippe, W. Alps), J. Metamorph. Geol., 35, 471-492, 2017.

Austrheim, H., Erambert, M., and Boundy, T. M.: Garnets recording deep crustal earthquakes, Earth Planet. Sc. Lett., 139, 223-238, https://doi.org/10.1016/0012-821X(95)00232-2, 1996.

Austrheim, H., Dunkel, K. G., Plümper, O., Ildefonse, B., Liu, Y., and Jamtveit, B.: Fragmentation of wall rock garnets during deep crustal earthquakes, Science Advances, 3, e1602067, https://doi.org/10.1126/sciadv.1602067, 2017.

Baxter, E. F. and Scherer, E. E.: Garnet Geochronology: Timekeeper of Tectonometamorphic Processes, Elements, 9, 433-438, https://doi.org/10.2113/gselements.9.6.433, 2013.

Behr, W. M. and Platt, J. P.: A naturally constrained stress profile through the middle crust in an extensional terrane, Earth Planet. Sc. Lett., 303, 181-192, 2011.
Bell, T. H.: Progressive deformation and reorientation of fold axes in a ductile mylonite zone: the Woodroffe thrust, Tectonophysics, 44, 285-320, 1978.

Bestmann, M., Habler, G., Heidelbach, F., and Thöni, M.: Dynamic recrystallization of garnet and related diffusion processes, J. Struct. Geol., 30, 777-790, https://doi.org/10.1016/j.jsg.2008.02.007, 2008.

Byerlee, J.: Friction of rocks, in Rock friction and earthquake prediction, Springer, 615-626, https://doi.org/10.1007/978-3-03487182-2_4, 1978

Caddick, M. J., Konopasek, J., and Thompson, A. B.: Preservation of Garnet Growth Zoning and the Duration of Prograde Metamorphism, J. Petrol., 51, 2327-2347, https://doi.org/10.1093/petrology/egq059, 2010.

Camacho, A. and Fanning, C. M.: Some isotopic constraints on the evolution of the granulite and upper amphibolite facies terranes in the eastern Musgrave Block, central Australia, Precambrian Res., 71, 155-181, 1995.

Camacho, A.: An Isotopic Study of Deep-Crustal Orogenic Processes: Musgrave Block, Central Australia, PhD Thesis, The Australian National University, Canberra, Australia, 1997.

Camacho, A. and Fitz Gerald, J. D.: Misidentification of oxide phases and of twinned kyanite: implications for inferred P-T histories of the Musgrave Block, central Australia, Journal of the Virtual Explorer, 35, https://doi.org/10.3809/jvirtex.2011.00275, 2010.

Camacho, A., Vernon, R. H., and Fitz Gerald, J. D.: Large volumes of anhydrous pseudotachylyte in the Woodroffe Thrust, eastern Musgrave Ranges, Australia, J. Struct. Geol., 17, 371-383, 1995.

Camacho, A., Compston, W., McCulloch, M., and McDougall, I.: Timing and exhumation of eclogite facies shear zones, Musgrave Block, central Australia, J. Metamorph. Geol., 15, 735751, 1997.

Camacho, A., Yang, P., and Frederiksen, A.: Constraints from diffusion profiles on the duration of high-strain deformation in thickened crust, Geology, 37, 755-758, 2009.

Collerson, K. D., Oliver, R. L., and Rutland, R. W. R.: An example of structural and metamorphic relationships in the Musgrave orogenic belt, central Australia, J. Geol. Soc. Aust., 18, 379-393, https://doi.org/10.1080/00167617208728776, 1972.

Dalziel, I. W. D. and Bailey, S. W.: Deformed garnets in a mylonitic rock from the Grenville Front and their tectonic significance, Am. J. Sci., 266, 542-562, https://doi.org/10.2475/ajs.266.7.542, 1968.

Ellis, S. and Stöckhert, B.: Elevated stresses and creep rates beneath the brittle-ductile transition caused by seismic faulting in the upper crust, J. Geophys. Res., 109, B05407, https://doi.org/10.1029/2003JB002744, 2017.

Engi, M., Giuntoli, F., Lanari, P., Burn, M., Kunz, B. E., and Bouvier, A.-S.: Pervasive eclogitization due to brittle deformation and rehydration of subducted basement: Effects on continental recycling?, Geochem. Geophy. Geosy., 19, 865-881, https://doi.org/10.1002/2017GC007215, 2018.

Evins, P. M., Smithies, R. H., Howard, H. M., Kirkland, C. L., Wingate, M. T. D., and Bodorkos, S.: Redefining the Giles Event within the setting of the 1120-1020 Ma Ngaanyatjarra Rift, West Musgrave Province, Central Australia, Geological Society of Western Australia, East Perth, WA, 2010. 
Giuntoli, F., Lanari, P., and Engi, M.: Deeply subducted continental fragments - Part 1: Fracturing, dissolution-precipitation, and diffusion processes recorded by garnet textures of the central Sesia Zone (western Italian Alps), Solid Earth, 9, 167-189, https://doi.org/10.5194/se-9-167-2018, 2018.

Gray, C. M.: Geochronology of granulite - facies gneisses in the western Musgrave Block, Central Australia, J. Geol. Soc. Aust., 25, 403-414, https://doi.org/10.1080/00167617808729050, 1978.

Hawemann, F.: Dataset "Fracturing and Crystal Plasticity of Garnet under Seismic Stress in the Dry Lower Continental Crust (Musgrave Ranges, Central Australia)", OSF, https://doi.org/10.17605/OSF.IO/YRZGH, version of 15 June 2019.

Hawemann, F., Mancktelow, N. S., Wex, S., Camacho, A., and Pennacchioni, G.: Pseudotachylyte as field evidence for lower-crustal earthquakes during the intracontinental Petermann Orogeny (Musgrave Block, Central Australia), Solid Earth, 9, 629-648, https://doi.org/10.5194/se-9-629-2018, 2018.

Hawemann, F., Mancktelow, N. S., Pennacchioni, G., Wex, S., and Camacho, A.: Weak and slow, strong and fast: How shear zones evolve in a dry continental crust (Musgrave Ranges, Central Australia), J. Geophys. Res.-Sol. Ea., 124, 219-240, https://doi.org/10.1029/2018JB016559, 2019.

Hobbs, B. E.: Recrystallisation of single crystals of quartz, Tectonophysics, 6, 353-401, 1968.

Hofer, H. E. and Brey, G. P.: The iron oxidation state of garnet by electron microprobe: Its determination with the flank method combined with major-element analysis, Am. Mineral., 92, 873885, https://doi.org/10.2138/am.2007.2390, 2007.

Jamtveit, B., Ben-Zion, Y., Renard, F., and Austrheim, H.: Earthquake-induced transformation of the lower crust, Nature, 556, 487-491, 2018a.

Jamtveit, B., Moulas, E., Andersen, T. B., Austrheim, H., Corfu, F., Petley-Ragan, A., and Schmalholz, S. M.: High pressure metamorphism caused by fluid induced weakening of deep continental crust, Sci. Rep., 8, 17011, https://doi.org/10.1038/s41598018-35200-1, 2018b.

Jamtveit, B., Petley-Ragan,A., Incel, S., Dunkel, K.G., Aupart,C., Austrheim, H., Corfu, F., Menegon, L., and Renard, F: The effects of earthquakes and fluids on the metamorphism of the lower continental crust, J. Geophys. Res.-Sol. Ea., https://doi.org/10.1029/2018jb016461, 2019.

Ji, S., Zhao, P., and Saruwatari, K.: Fracturing of garnet crystals in anisotropic metamorphic rocks during uplift, J. Struct. Geol., 19, 603-620, 1997.

Karato, S., Wang, Z., Liu, B., and Fujino, K.: Plastic deformation of garnets: systematics and implications for the rheology of the mantle transition zone, Earth Planet. Sc. Lett., 130, 13-30, 1995.

Kirkpatrick, J. D. and Rowe, C. D.: Disappearing ink: How pseudotachylytes are lost from the rock record, J. Struct. Geol., 52, 183-198, https://doi.org/10.1016/j.jsg.2013.03.003, 2013.

Konrad-Schmolke, M., O'Brien, P. J., and Heidelbach, F.: Compositional reequilibration of garnet: the importance of sub-grain boundaries, Eur. J. Mineral., 19, 431-438, 2007.

Kunze, K., Wright, S. I., Adams, B. L., and Dingley, D. J.: Advances in automatic EBSP single orientation measurements, Texture, Stress, and Microstructure, 20, 41-54, 1993.
Lasaga, A. C.: Geospeedometry: an extension of geothermometry, in Kinetics and equilibrium in mineral reactions, Springer, 81-114, available at: http://link.springer.com/chapter/10.1007/ 978-1-4612-5587-1_3 (last access: 28 May 2017), 1983.

Major, R. B.: Explanatory Notes for the Woodroffe 1 : 250000 Geological Map SG/52-12, 1st Edn., Adelaide, Australia, Geological Survey of South Australia, 1973.

Mancktelow, N. S.: Tectonic pressure: Theoretical concepts and modelled examples, Lithos, 103, 149-177, https://doi.org/10.1016/j.lithos.2007.09.013, 2008.

Massey, M. A., Prior, D. J., and Moecher, D. P.: Microstructure and crystallographic preferred orientation of polycrystalline microgarnet aggregates developed during progressive creep, recovery, and grain boundary sliding, J. Struct. Geol., 33, 713-730, https://doi.org/10.1016/j.jsg.2010.12.009, 2011.

Menegon, L., Pennacchioni, G., Malaspina, N., Harris, K., and Wood, E.: Earthquakes as precursors of ductile shear zones in the dry and strong lower crust, Geochem. Geophy. Geosy., 18, 4356-4374, https://doi.org/10.1002/2017GC007189, 2017.

Papa, S., Pennacchioni, G., Angel, R. J., and Faccenda, M.: The fate of garnet during (deep-seated) coseismic frictional heating: The role of thermal shock, Geology, 46, 471-474, https://doi.org/10.1130/G40077.1, 2018.

Passchier, C. W. and Trouw, R. A. J.: Microtectonics, 2nd Edn., Springer, Heidelberg, 366 pp., 2005.

Petley-Ragan, A., Ben-Zion, Y., Austrheim, H., Ildefonse, B., Renard, F., and Jamtveit, B.: Dynamic earthquake rupture in the lower crust, Science Advances, 5, eaaw0913, https://doi.org/10.1126/sciadv.aaw0913, 2019.

Prior, D. J.: Sub-critical fracture and associated retrogression of garnet during mylonitic deformation, Contrib. Mineral. Petr., 113, 545-556, https://doi.org/10.1007/BF00698322, 1993.

Prior, D. J., Wheeler, J., Brenker, F. E., Harte, B., and Matthews, M.: Crystal plasticity of natural garnet: New microstructural evidence, Geology, 28, 1003, https://doi.org/10.1130/00917613(2000)28<1003:CPONGN>2.0.CO;2, 2000.

Prior, D. J., Wheeler, J., Peruzzo, L., Spiess, R., and Storey, C.: Some garnet microstructures: an illustration of the potential of orientation maps and misorientation analysis in microstructural studies, J. Struct. Geol., 24, 999-1011, https://doi.org/10.1016/S0191-8141(01)00087-6, 2002.

Raimondo, T., Collins, A. S., Hand, M., Walker-Hallam, A., Smithies, R. H., Evins, P. M., and Howard, H. M.: The anatomy of a deep intracontinental orogen, Tectonics, 29, TC4024, https://doi.org/10.1029/2009TC002504, 2010.

Scrimgeour, I. and Close, D.: Regional high-pressure metamorphism during intracratonic deformation: The Petermann Orogeny, central Australia, J. Metamorph. Geol., 17, 557-572, https://doi.org/10.1046/j.1525-1314.1999.00217.x, 1999.

Scrimgeour, I. R., Close, D. F., and Edgoose, C. J.: 1 : 25000 Geological Map Series and Explanatary Notes. Petermann Ranges SG52-7, 2nd Edn., North. Territ. Geol. Surv., Darwin, Australia, 1999.

Shimada, M., Cho, A., Yukutake, H.: Fracture strength of dry silicate rocks at high confining pressures and activity of acoustic emission, Tectonophysics, 96, 159-172, https://doi.org/10.1016/0040-1951(83)90248-2, 1983.

Sibson, R. H.: Generation of pseudotachylyte by ancient seismic faulting, Geophys. J. Int., 43, 775-794, 1975. 
Sibson, R. H. and Toy, V. G.: The habitat of fault-generated pseudotachylyte: Presence vs. absence of friction-melt, in: Geophysical Monograph Series, Vol. 170, edited by: Abercrombie, R., McGarr, A., Kanamori, H., and Di Toro, G., 153-166, American Geophysical Union, Washington, DC, https://doi.org/10.1029/170GM16, 2006.

Toy, V. G., Ritchie, S., and Sibson, R. H.: Diverse habitats of pseudotachylytes in the Alpine Fault Zone and relationships to current seismicity, Geological Society, London, Special Publications, 359, 115-133, https://doi.org/10.1144/SP359.7, 2011.

Trepmann, C. A. and Stöckhert, B.: Cataclastic deformation of garnet: a record of synseismic loading and postseismic creep, J. Struct. Geol., 24, 1845-1856, https://doi.org/10.1016/S01918141(02)00004-4, 2002.

Voegelé, V., Cordier, P., Sautter, V., Sharp, T. G., Lardeaux, J. M., and Marques, F. O.: Plastic deformation of silicate garnets, Phys. Earth Planet. In., 108, 319-338, https://doi.org/10.1016/S00319201(98)00111-3, 1998

Vollbrecht, A., Pawlowski, J., Leiss, B., Heinrichs, T., Seidel, M., and Kronz, A.: Ductile deformation of garnet in mylonitic gneisses from the Münchberg Massif (Germany), Tectonophysics, 427, 153-170, https://doi.org/10.1016/j.tecto.2006.05.024, 2006.
Wang, Z. and Ji, S.: Deformation of silicate garnets; brittle-ductile transition and its geological implications, Can. Mineral., 37, 525-541, 1999.

Wayte, G. J., Worden, R. H., Rubie, D. C., and Droop, G. T. R.: A TEM study of disequilibrium plagioclase breakdown at high pressure: the role of infiltrating fluid, Contrib. Mineral. Petr., 101, 426-437, https://doi.org/10.1007/BF00372216, 1989.

Wex, S., Mancktelow, N. S., Hawemann, F., Camacho, A., and Pennacchioni, G.: Geometry of a large-scale, lowangle, mid-crustal thrust (Woodroffe Thrust, central Australia): Geometry of a mid-crustal thrust, Tectonics, 2447-2476, https://doi.org/10.1002/2017TC004681, 2017.

Wex, S., Mancktelow, N. S., Hawemann, F., Camacho, A., and Pennacchioni, G.: Inverted distribution of ductile deformation in the relatively "dry" middle crust across the Woodroffe Thrust, central Australia, Solid Earth, 9, 859-878, https://doi.org/10.5194/se-9-859-2018, 2018.

Wex, S., Mancktelow, N. S., Camacho, A., and Pennacchioni, G.: Interplay between seismic fracture and aseismic creep in the Woodroffe Thrust, central Australia - Inferences for the rheology of relatively dry continental mid-crustal levels, Tectonophysics, 758, 55-72, https://doi.org/10.1016/j.tecto.2018.10.024, 2019.

Whitney, D. L. and Evans, B. W.: Abbreviations for names of rock-forming minerals, Am. Mineral., 95, 185-187, https://doi.org/10.2138/am.2010.3371, 2010. 